\title{
Remediation of Pulp and Paper Industry Effluent Using Electrocoagulation Process
}

\author{
Dushyant Kumar, Chhaya Sharma* \\ Environmental Research Laboratory, Department of Paper Technology, Indian Institute of Technology Roorkee, Saharanpur \\ Campus, Saharanpur, India \\ Email: *chhaya1964@rediffmail.com
}

How to cite this paper: Kumar, D. and Sharma, C. (2019) Remediation of Pulp and Paper Industry Effluent Using Electrocoagulation Process. Journal of Water Resource and Protection, 11, 296-310.

https://doi.org/10.4236/jwarp.2019.113017

Received: February 2, 2019

Accepted: March 12, 2019

Published: March 15, 2019

Copyright $\odot 2019$ by author(s) and Scientific Research Publishing Inc. This work is licensed under the Creative Commons Attribution International License (CC BY 4.0).

http://creativecommons.org/licenses/by/4.0/

\section{(c) () Open Access}

\begin{abstract}
Electrocoagulation of pulp and paper industry effluent with SS-304 electrode has been carried out under varying process variable such as $\mathrm{pH}$, current density, time and dose of electrolyte to find out the optimum conditions. Maximum reduction efficiency of Chemical Oxygen Demand (COD) $82 \%$ and color more than $99 \%$ from pulp and paper industry wastewater at the following conditions $\mathrm{pH}=7$, current density $=24.80 \mathrm{~mA} / \mathrm{cm}^{2}$ time $=40 \mathrm{~min}$ and dose of electrolytes $=1.0 \mathrm{~g} / \mathrm{L}$. Moreover, effects of electrolytes dosage on electricity consumption were observed and found to be that $\mathrm{NaCl}$ is better in comparison of $\mathrm{Na}_{2} \mathrm{SO}_{4}$ in respect of lower down the electricity consumption. But application of $\mathrm{NaCl}$ causes the formation of hazardous compounds as secondary pollutants within treated water. Therefore, $\mathrm{Na}_{2} \mathrm{SO}_{4}$ could be a potent replacement of $\mathrm{NaCl}$ to enhance the conductivity of paper industry effluent treated by EC process. The treated water has been compared with standard of Central Pollution control board (CPCB) and World Health organization, and found to be suitable for the reuse in irrigation.
\end{abstract}

\section{Keywords}

Pulp Paper Industry, Electrocoagulation Treatment, Wastewater, Reuse, Chemical Oxygen Demand, Color

\section{Introduction}

The manufacturer of paper fundamentally relies upon the natural resources such as water, forest, agro-product, and fossil fuels (energy) for the production of paper [1]. The huge amount of fresh water is consumed coarse of Pulp and paper 
making process. These processes are preparation of wood, pulping, washing of pulp and bleaching which releases large volume of effluent along with high organic load, COD, Biological Oxygen Demand (BOD), colorant and lower biodegradability index. The paper industry effluent is a complicated blend of more than 250 organic and 700 inorganic chemicals [2]. Additionally, highly toxic chemicals which are resistant to biodegradation and listed as prime contaminates by United States Environmental Protection Agency (USEPA) which are related to severe health concern, generates mainly reaction between lignin and chorine/chlorine based chemical still being used for the bleaching of pulp [3]. Chlorinated phenolic compounds such as chlorophenolics, chloro-hydrocarbon, and fatty acid are also present in wastewater. Some of them i.e. chlorophenolics, dioxin and furan show the higher toxicity. When this effluent is released without appropriate treatment, it influences the negative effect on receiving water bodies involving thermal impacts, low Dissolved Oxygen (DO), poor sunlight penetration, scum formation, slime growth, and harming the aesthetic and scenic beauty of environment and disturbed the overall ecosystem. Some investigator reported the toxic effect on fish present and growing in the water bodies containing paper industry effluent. The Indian paper industry used mainly two-step treatment at their treatment plants such as primary (sedimentation, floatation) and secondary (activated sludge, anaerobic or aerobic process). These methods are failed to meet the requirements of complete degradation of bio-refractory compounds, COD and color including some drawback such as high treatment cost and generating high volume of sludge, which consequently may be responsible for secondary pollution. Hence, there is an urgent need to stop the formation or to impose suitable measures for the degradation of these dreadful chemical by modification in plant. Meanwhile an effective treatment facility is becoming a necessity to remove these pollutants from wastewater [3] [4] [5] [6].

Nowadays electrocoagulation (EC) method has intensively attracted the researchers from around the world due to its unique feature in comparison to the chemical and biological treatment facility. EC process exhibits environmental compatibility, proper setup, shorter reaction time, meager chemical requirement along with negligible generation of sludge [7]. The main acting reagents in this process are electrons which are clean reagent [8]. Recently, EC method has been considered as an advanced oxidation process and successfully applied for treatment of the different types of industry effluent including organics matter, phenolic compounds, potato chips manufacturing unit, methylparathion from textile unit, colorants from dye solutions, oil suspensions, and fluorides [9]-[15]. When the direct current is supplied between anode and cathode, the metal plates dissipate and release the positive hydroxide ions at desired $\mathrm{pH}$ [16]. In the present investigation, stainless steel (SS)-304 has been used as electrode material. When oxidation occurred at $\mathrm{Fe}$ anode, it may produces iron hydroxide, $\mathrm{Fe}(\mathrm{OH})_{n}$, where $n=2$ or 3 . The mechanisms for the production of $\mathrm{Fe}(\mathrm{OH})_{n}$ of the process is given as follows: 
At anode:

$$
\begin{gathered}
\mathrm{Fe}_{(\mathrm{s})} \rightarrow \mathrm{Fe}_{(\mathrm{aq})}^{2+}-2 \mathrm{e}^{-} \\
\mathrm{Fe}_{(\mathrm{aq})}^{2+}+2(\mathrm{OH})_{(\mathrm{aq})} \rightarrow \mathrm{Fe}(\mathrm{OH})_{2(\mathrm{~s})}
\end{gathered}
$$

At cathode:

$$
2 \mathrm{H}_{2} \mathrm{O}_{(\mathrm{I})}+2 \mathrm{e}^{-} \rightarrow \mathrm{H}_{2(\mathrm{~g})}+2 \mathrm{OH}_{(\mathrm{aq})}^{-}
$$

Overall reaction:

$$
\mathrm{Fe}_{(\mathrm{s})}+2 \mathrm{H}_{2} \mathrm{O}_{(\mathrm{I})} \rightarrow \mathrm{Fe}(\mathrm{OH})_{2(\mathrm{~s})}+\mathrm{H}_{2(\mathrm{~g})}
$$

These $\mathrm{Fe}(\mathrm{OH})_{n}$ metal ions behave as coagulant or destabilize the pollutants present in wastewater by charge neutralization and having a great potential to separate them by electro-flotation. In recent years, the EC process has usually been used for the separation of pollutants present in different types of water and wastewater [7] [17] [18]. As for increasing environmental awareness and strictness in polices, force to adopt integrative management practice for wastewater treatment. On the other hand, research related to wastewater treatment and reuse is poorly reported. As per our knowledge very hardly any study has been conducted to develop the optimum treatment conditions and suggestion of reusability of EC treated water for irrigation. The aims of this work to determine the optimum condition correspondence to the maximum COD and color removal from paper industry waste effluent. Further, find out an alternative option for the utilization of treated water in agriculture.

\section{Material and Methods}

\subsection{Characteristics of Effluent}

The wastewater has been collected after primary treatment from nearby paper industry followed by immediate storage at temperature below than $4^{\circ} \mathrm{C}$. The analysis of the samples for several parameters such as $\mathrm{pH}, \mathrm{BOD}_{3}$, COD TOC, color and TDS were performed as per standard method [5] and observation are given in Table 1 . The conductivity and $\mathrm{pH}$ of the effluent have been performed by a digital conductivity meter and calibrated $\mathrm{pH}$ meter, respectively. The treatment efficiency (TE) was also determined in terms of maximum COD and color elimination percentage from effluent by the following equation;

$$
\text { Treatment efficiency }(\mathrm{TE} \%)=C_{0}-C_{t} / C_{0} \times 100
$$

where,

$\mathrm{TE}=$ Treatment efficiency (\%), $C_{0}=$ Initial concentration of pollutants, $C_{t}=$ concentration of pollutants after time $(t)$.

$$
\text { Total Energy consumption }\left(\mathrm{kWh} / \mathrm{m}^{3}\right)=\frac{V I t}{\text { Treated volume }(l)}
$$

where, $V=$ Volume potential of electricity $(\mathrm{V}), I=$ Current (ampere), $t=$ time of treatment $(\mathrm{h})$ and $l$ is the treated volume in liter [19]. 
Table 1. The major characteristics of paper industry effluent.

\begin{tabular}{ccc}
\hline S. No. & Parameters & Values \\
\hline 1 & $\mathrm{pH}$ & 7.65 \\
2 & $\mathrm{BOD}(\mathrm{mg} / \mathrm{L})$ & 176 \\
3 & $\mathrm{COD}(\mathrm{mg} / \mathrm{L})$ & 534 \\
4 & BOD $/ \mathrm{COD}$ & 0.32 \\
5 & TOC $(\mathrm{mg} / \mathrm{L})$ & 209 \\
6 & Color $(\mathrm{Pt} . \mathrm{Co} . \mathrm{Units})$ & 1154 \\
7 & TDS $(\mathrm{mg} / \mathrm{L})$ & 1858 \\
8 & Conductivity $(\mathrm{mS})$ & 3.32 \\
\hline
\end{tabular}

\subsection{Electrocoagulation Unit}

The batch scale laboratory diagram of experimental assembly is depicted in Figure 1.

The electrode configuration and EC experiment details are depicted in Table 2. The EC tests have been done in a $250 \mathrm{ml}$ plastic beaker at ambient temperature. Direct current power supply was used for supplying the current in reaction vessel. The stirrer has been used at $100 \mathrm{rpm}$ for continuous stirring of media during the test. EC method has its own drawback as it uses vast quantity of electricity (exhaustible source). Keeping the environmental concern in mind, the experimental setup is connected to the photovoltaic cell (solar energy) to reduce the electricity

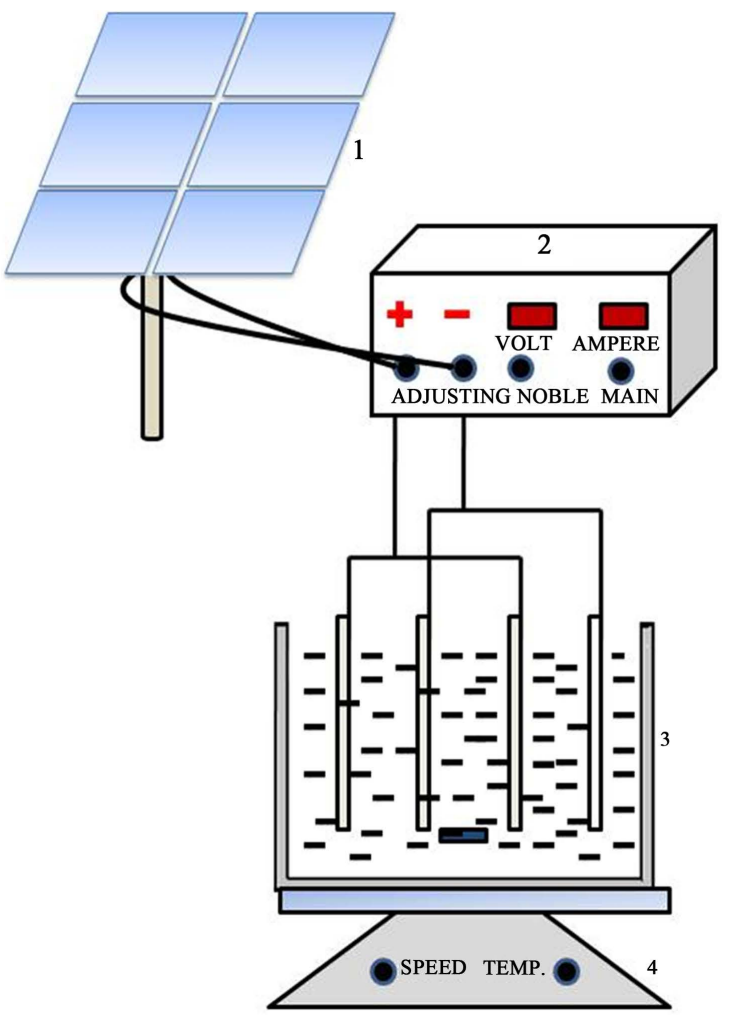

Figure 1. Laboratory scale experimental setup of electrocoagulation unit (1-Solar panel, 2-Direct current supply and 3-Treatment vessel, consists of Anode and Cathode in mono-polar mode, magnetic-bead, and 4-magnetic stirrer). 
Table 2. Characteristics of electrode and treatment assembly.

\begin{tabular}{ccc}
\hline S. No. & Electrode characteristics & \\
\hline 1 & Material (anode and cathode) & SS-304 \\
2 & Shape & Rectangular \\
3 & Size $(\mathrm{mm})$ & $40 \times 70$ \\
4 & Number & 4 \\
5 & Plate arrangement & Parallel \\
6 & Connection mode & Monopolar \\
7 & Effective area of electrode (mm $\left.{ }^{2}\right)$ & 504 \\
& Reactor characteristics & \\
8 & Make & Plastic \\
9 & Mode & Batch \\
10 & Volume (ml) & 250 \\
11 & Used water volume (ml) & 250 \\
12 & Electrode gap (mm) & 10 \\
13 & Power supply & Direct current \\
14 & Voltage range (V) & $1-12$ \\
15 & Current range (A) & mA $/ \mathrm{cm}^{2}$ \\
\hline
\end{tabular}

consumption. During the EC treatment, direct current is used so that solar energy could be quite meaningful to dealing with the treatment of water and wastewater at laboratory and industrial scale. Since India is considered to be a tropical country and having vast solar energy potential, it could be more attractive option for the usage of EC process. Moreover, Photovoltaic cells produce the direct current which is directly used in EC process without any change making it an affordable alternative for the treatment of wastewater facilitated by EC process. Earlier reports have also asserted on the successful treatment of different types of industrial effluents by EC [20] [21] [22] [23] [24].

\section{Result and Discussion}

\subsection{Parameter Optimization}

Pulp and paper industry effluent found to be intensively polluted in nature with heavy organic load in terms of COD and color. This study investigates the optimum conditions for EC on the basis of maximum COD and color removal by varying several variables such as $\mathrm{pH}$ (5.0 - 9.0), time (10 - $50 \mathrm{~min})$, current density $\left(4.96-34.72 \mathrm{~mA} / \mathrm{cm}^{2}\right)$ and electrolytes dose $(0.5-2.0 \mathrm{~g} / \mathrm{L})$.

\subsection{Effect of $\mathrm{pH}$}

It has been extensively studied that the $\mathrm{pH}$ is one of the crucial parameter to govern the efficiency of EC method [25] [26] [27]. In this investigation, the effect of $\mathrm{pH}$ was observed for the reduction of COD, and Color from paper industry 
wastewater for its treatment. A sequence of experiment was conducted by varying the $\mathrm{pH}$ from $\mathrm{pH} 5.0$ to $\mathrm{pH} 9.0$, while other parameters like current density 5 $\mathrm{mA} / \mathrm{cm}^{2}$, time $10 \mathrm{~min}$ and dose of electrolyte $0.5 \mathrm{~g} / \mathrm{L}$ remained constant. This is clear from Figure 2 when the $\mathrm{pH}$ of media was changing from $5-7$, the COD and Color reduction rises gradually due to the occurrence of freshly formed $\mathrm{Fe}(\mathrm{OH})_{n}$ and maximum reduction was found to be near $\mathrm{pH}$ 7.0. These Fe ions possess a large surface area and higher affinity for coagulation. In addition, it was also observed that $\mathrm{pH}$ in basic medium causes the solubility of $\mathrm{Fe}(\mathrm{OH})_{3}$ to increase which leads to the formation of $\mathrm{Fe}(\mathrm{OH})_{4}$ which ineffective for the treatment of wastewater treatment [27] [28] [29] [30]. The efficiency of treatment was not observed to be good at acidic or basic medium while it is lowest at pH 5 and $\mathrm{pH} 9$ respectively.

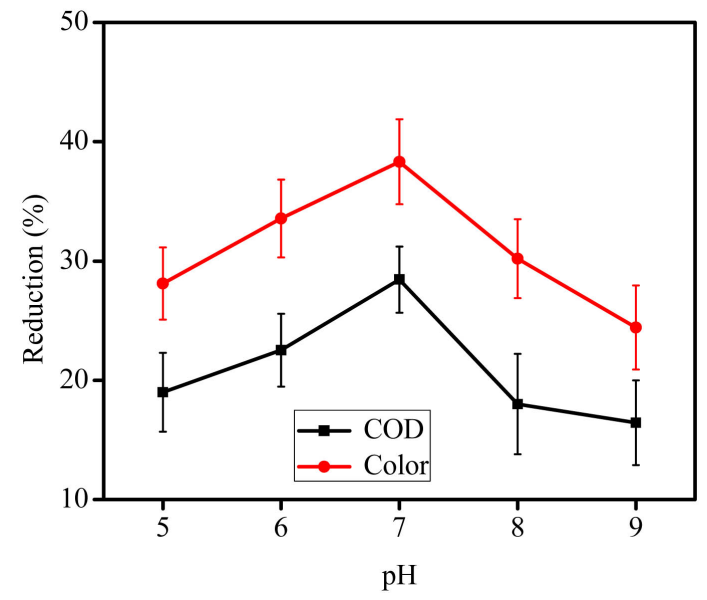

Figure 2. Effect of $\mathrm{pH}$ on $\mathrm{COD}$ and color removal.

Moreover, the EC method exhibits buffering effect which makes the EC process unique in terms of feasibility for wastewater treatment. Therefore, it is not required to maintain the $\mathrm{pH}$ of treated water before releasing it into water system. Additionally the treated water of either acidic or basic $\mathrm{pH}$ can cause several negative effects on receiving water bodies and entire ecosystem [5] [31].

\subsection{Effect of Current Density}

Various study described that current density is a major parameter which leads to the higher treatment efficiency and is also cost effective for the EC process [19] [29] [32] [33]. The current density was varied from $4.96-34.72 \mathrm{~mA} / \mathrm{cm}^{2}$ for reducing the COD and color content from waste effluent (Figure 3). It was noticed that as the current density increases, it led to greater amount of metal dissolution or anodic oxidation which in turn leads to high precipitation of hydroxy cationic complexes. It is obvious that applied current density enhance the rate of bubble production along with the rate of coagulant (flocs formation) which is beneficial for the treatment efficiency of the EC.

Besides, it is also reported that bubbles density increases and their size decrease 


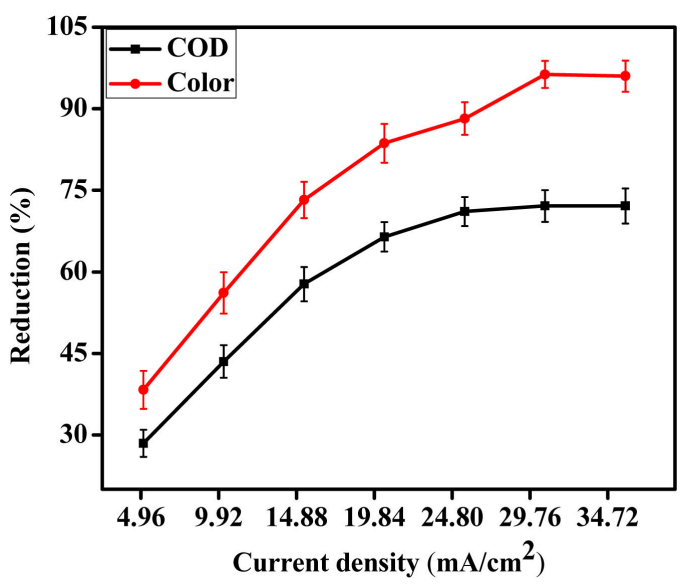

Figure 3. Effect of current density on COD and color removal.

by means of rising current density ensuing a larger upwards flux and more rapid removal of pollutants and sludge flotation [33] [34]. In this study it was observed that the removal efficiency of pollutants and current density are directly proportional to each other.

\subsection{Effect of Treatment Time}

The effect of treatment period was investigated to varying time intervals (10 - 50 $\min ), \mathrm{pH}$, current density, dose of electrolyte fixed at 7, $24.80 \mathrm{~mA} / \mathrm{cm}^{2}$ and 0.5 $\mathrm{g} / \mathrm{L}$, respectively to find out the reduction in COD and color in present effluent sample. At the beginning of the run, the solution was transparent which progressively becomes dark and after about $30 \mathrm{~min}$ it turns greenish as the reaction progress due to formation of $\mathrm{Fe}(\mathrm{OH})_{\mathrm{n}(\mathrm{s})}$. After about 10 min a significant reduction in color was observed (Figure 4$)$ and at the end of the treatment ( 40 min) reduction in color value reached up to $97 \%$ (Figure 4). The color of Fe ion disappears slowly with the progression of time since the produced Fe ions mostly coagulant with the pollutant species and form settleable sludge [35] [36] [37]. Same pattern was observed in the case of COD reduction, as it was observed that an increasing in the time leads to increase in the removal efficiency of COD. A

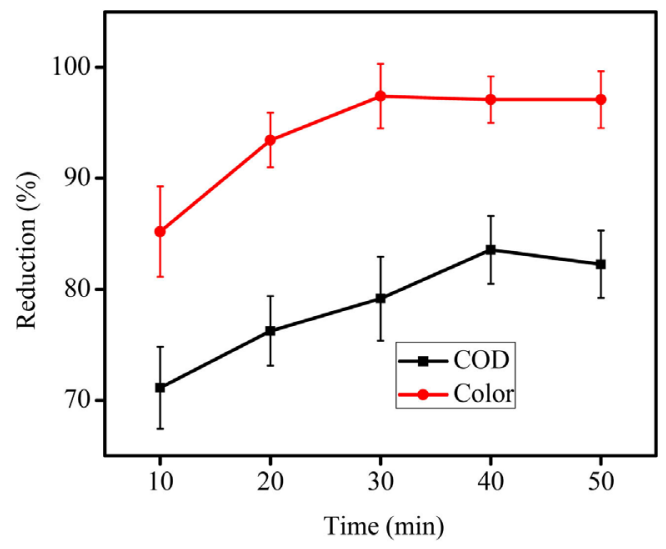

Figure 4. Effect of time on COD and color removal. 
removal of $81 \%$ in COD value was observed in $40 \mathrm{~min}$ time and after that the small changes occurred in value of COD and finally plot become constant.

Thereafter, no reduction was observed in the COD and color found to be in a nearly steady state. Therefore, $40 \mathrm{~min}$ is taken as the optimum time for the degradation of the organic matter in the present effluent sample [37].

\subsection{Effect of the Supporting Electrolyte on Process Efficiency and Electricity Consumption}

The conductivity of solution plays a key role to boost the process efficiency and reduce the current density. Conductivity maintains the lower potential flowing in circuit during the treatment and reduced electricity energy consumption (EEC) [38]. The heterogeneous ions transferred in the EC method due to the conductivity of the effluent. In this treatment two electrolytes have been used which are $\mathrm{Na}_{2} \mathrm{SO}_{4}$ and $\mathrm{NaCl}$.

The effect of variable concentrations of electrolytes $(0.5-2.0 \mathrm{~g} / \mathrm{L})$ was observed on the removal of chemical oxygen demand and color and the EEC consumption. EC process was performed using current density of $24.80 \mathrm{~mA} / \mathrm{cm}^{2}$, time $40 \mathrm{~min}$ and $\mathrm{pH}$ 7. As shown in Figure 5, when the concentration of both $\mathrm{Na}_{2} \mathrm{SO}_{4}$ and $\mathrm{NaCl}$ from 0.5 to $1 \mathrm{~g} / \mathrm{L}$ the increment in removal efficiency was observed, from 79 - 84. This may be due to the rapid movement of ions of electrolytes. Moreover, when the supporting electrolyte concentration is increased to 2 $\mathrm{g} / \mathrm{L}$, no further improvement is found in removal efficiency which may be due to an increasing of the passivation layer [27] [39].

The existence of the sustaining electrolyte also cut down the EEC, as revealed in Figure 6. This may be due to the increase of the conductance of solution, and leads the countable effect in EEC from $28 \mathrm{kWh} / \mathrm{m}^{3}$ to $16.5 \mathrm{kWh} / \mathrm{m}^{3}$ using $1 \mathrm{~g} / \mathrm{L}$ supporting electrolyte (Figure 6). Consequently, a value of $1 \mathrm{~g} / \mathrm{L}$ concentration of the electrolyte was preferred to acquire high removal efficiency of treatment, as well as to reduce EEC. During the treatment EEC of the wastewater was also reliant on process time. The EEC found to be directly proportional with increasing process time and linearly increases from 0.848 to $16.50 \mathrm{kWh} / \mathrm{m}^{3}$ with an increasing process time from 10 to $40 \mathrm{~min}$ at the $24.80 \mathrm{~mA} / \mathrm{cm}^{2}$ current density and $1 \mathrm{~g} / \mathrm{L} \mathrm{Na}_{2} \mathrm{SO}_{4}$. Additionally, a highest COD reduction of near about $82 \%$ was observed after $40 \mathrm{~min}$, whereas reduction in COD at $60 \mathrm{~min}$ was about $80 \%$. The $\mathrm{EEC}$ at $50 \mathrm{~min}$ was found to be higher in comparison of $40 \mathrm{~min}$ (Figure 6). A similar result was obtained for $1 \mathrm{~g} / \mathrm{L} \mathrm{NaCl}$. A removal efficiency of $82 \%$ was obtained using $\mathrm{Na}_{2} \mathrm{SO}_{4}$ at $16.5 \mathrm{kWh} / \mathrm{m}^{3} \mathrm{EEC}$, while same removal efficiency was found using $16.17 \mathrm{kWh} / \mathrm{m}^{3} \mathrm{EEC}$ when $\mathrm{NaCl}$ used as electrolyte. $\mathrm{NaCl}$ was observed quite effective in respect of EEC consumption in comparison to $\mathrm{NaSO}_{4}$ [17] [27]. Additionally, If $\mathrm{NaCl}$ used as electrolyte during the treatment of paper industry effluent, it may be quite harmful due to the presence of $\mathrm{Cl}^{-}$ions. Additionally, once the chloride ions added in the solution, they produced $\mathrm{Cl}_{2}$ and $\mathrm{OCl}^{-}$at anode. This $\mathrm{OCl}^{-}$take part in oxidation reaction and remove organic matter. These ions may reacts with lignin and phenols already present in wastewater, 


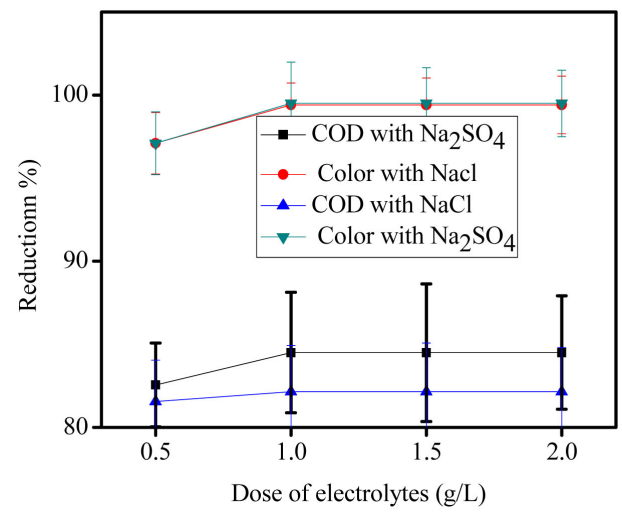

Figure 5. Effect of dose of electrolyte on COD and color removal.

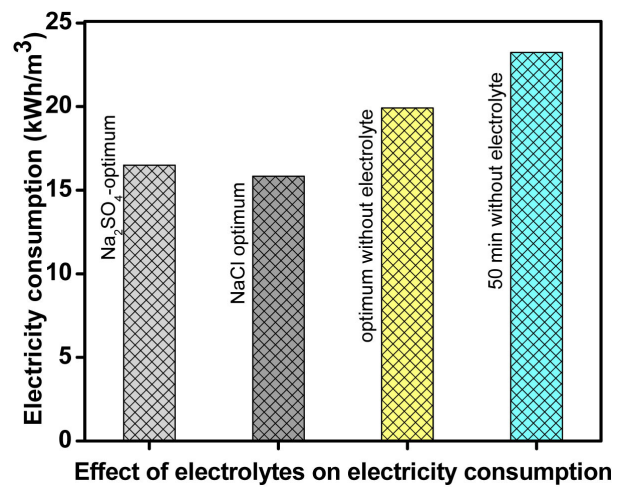

Figure 6. Effect of dose of electrolyte on electricity consumption.

and produced water soluble electrolignin, easily oxidizable chlorolignin and chlorophenolics compounds. Earlier researcher suggested that these compounds caused higher toxicity and disturbances in aquatic system [7] [40] [41]. Thus, $\mathrm{Na}_{2} \mathrm{SO}_{4}$ could be more favorable option for electrolyte for the treatment of pulp and paper industry wastewater using EC methods.

\subsection{Kinetics Study}

The kinetics of electro-coagulation was studied in order to assist the rate of reaction during the process of oxidation. Paper industry wastewater contains a mixture of various compounds with differential reactivity. Therefore, it is quite difficult to perform a detailed analysis of individual compounds. To study such a complicated process, the rate of reaction was studied in terms of a combined parameter (i.e. COD).

The experimental data observed with time-dependent COD removal in the presence of $\mathrm{Na}_{2} \mathrm{SO}_{4}$ as electrolyte modeled by the assumption of first-order kinetics where the progressive disappearance of COD can be presented as the percentage COD removal is proportional to the pollutant concentration and the numbers of hydroxides [flocks] generated (Figure 7). The rate equation can be written as [42]:

$$
\frac{-\mathrm{d}[\mathrm{COD}]}{\mathrm{d} t}=k[\mathrm{COD}]\left[\mathrm{Fe}(\mathrm{OH})_{3}\right]
$$




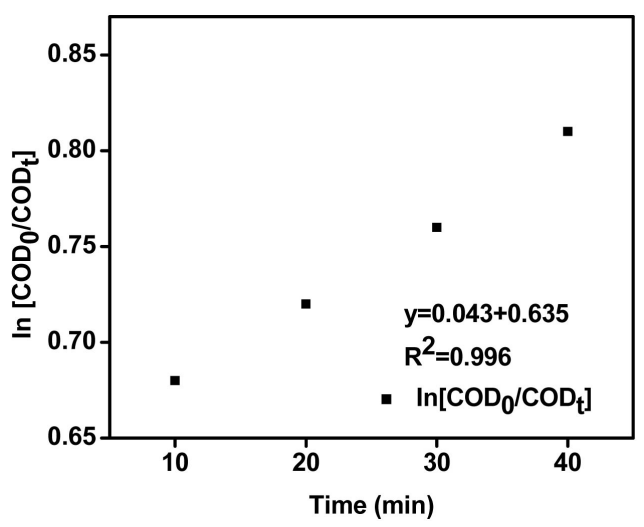

Figure 7. Linear fitting of $\ln \left[\mathrm{CODo} / \mathrm{COD}_{\mathrm{t}}\right]$ as a function of reaction time.

By the integration of equation (9) yields

$$
\log \frac{\left[\mathrm{COD}_{t}\right]}{\left[\mathrm{COD}_{0}\right]}=-k t
$$

where $\mathrm{COD}_{0}$ refers the initial effluent $\mathrm{COD}$ and $\mathrm{COD}_{t}$ refers the effluent $\mathrm{COD}$ at time $t$.

The reaction rate constant $k$, can be estimated from the plot $\log \left[\mathrm{COD}_{t} / \mathrm{COD}_{0}\right]$ versus electrolysis time. The experimental data fitted well to first order kinetics, as a straight line with an $\mathrm{R}^{2}$ value of 0.996 been critically examined.

\subsection{Reuse Option for Treated Water}

Water shortage is a fundamental problem at present in various parts of world which is badly influencing a huge portion of the world population. With this reality, farming emerges as one of the high water demands, it consuming about $70 \%$ of worldwide freshwater. Besides, $28 \%$ - 56\% of the worldwide irrigated cropland is situated in regions under high $(40 \%$ to $80 \%)$ or very high $(>80 \%)$ water pressure, in light of the proportion of water withdrawal over accessible water [43]. In this sense, water recovered from municipal wastewater has turned out to be one of the major and more affordable non-regular water hotspots for farming which is, with about 20 out of 200 million Ha (hectare) of irrigated land around the world, the main recycled water consumer and one of the less expensive in which its utilization demonstrates its genuine advantages. The irrigation of agricultural land by using reclaimed water having some advantages such as reduce the fresh water consumption and pressure over the fresh water sources, added high nutrient value to soil which diminish the uses of synthetic fertilizer and enhance the yields of crops in comparison of freshwater irrigated crops. On the other hand, mismanagement in wastewater reclamation may cause negative effect on human health along with environment. There are most possible concern is presence of pathogens which may enter in the food chain and can cause several diseases to flora and fauna. Additionally, land and crops might be affected by expanding salinity. (Phytotoxic components can influence development of products decreasing yields and the structure of soils may result in harm 
because of high sodicity levels.) Untreated wastewater discharges into the streams where it is diverted by subsistence agriculturists to little plots of vegetables and greens serving of mixed greens crops created for adjacent urban markets [44]. These primary vegetables are carrots, lettuce, cabbage and others which are smoothly devoured crude as plate of mixed greens and green vegetables. The general prosperity risks of using such dirtied streams for water framework are undeniable. Treated gushing can be used for horticulture framework under controlled conditions to restrain the trading of pathogenic and hurtful contaminants into the cultivating, soils, surface, and groundwater. The issues of lack of water and transfer wastewater in dry zones can be decreased by the use of treated water in agribusiness fields. Especially for less prolific soil, this might be fundamental wellspring of enhancements for harvest creation. Usage of treated water to cropland and forested region is an appealing option for exchange since it can improve the physical properties and the enhancement substance of soils [45]. Water system with treated water gives, supplement, for example, $\mathrm{N}$ and $\mathrm{P}$ and adding natural issue to the dirt, yet there is a dread about the gathering of perhaps unsafe segments, for instance compact disc, $\mathrm{Cr}, \mathrm{Cu}, \mathrm{Pb}, \mathrm{Fe}, \mathrm{Al}, \mathrm{Mn}, \mathrm{Zn}$, phenols, chlorophenol and their subordinates from paper plants wastewater [46]. In this study treated water was compared to the standard of CPCB and WHO provided for the irrigation in agriculture.

According to Table 3, all residual operating parameters were in the prescribed range of World Health Organization (WHO) and CPCB standard that ensure the reusability of treated water for irrigation purposes. This EC process and its applications are environmentally sustainable and economically viable.

Table 3. Comparison of studied treated water quality with CPCB and WHO wastewater reuse standards for irrigation in agriculture land [47].

\begin{tabular}{cccc}
\hline Characteristics & Treated water & PL $^{*}(\mathrm{CPCB})$ & PL $^{*}$ (WHO) \\
\hline $\mathrm{pH}$ & 7.25 & $5.5-9.0$ & $6-9$ \\
$\mathrm{BOD}(\mathrm{mg} / \mathrm{L})$ & 52 & 100 & 200 \\
$\mathrm{COD}(\mathrm{mg} / \mathrm{L})$ & 91 & $\mathrm{NA}$ & 500 \\
TDS (mg/ L) & 1059 & $\mathrm{NA}$ & 1500 \\
Color (Pt-Co. Units) & 6.93 & $\mathrm{NA}$ & $\mathrm{NA}$ \\
Conductivity (mS) & 2.83 & $\mathrm{NA}$ & $\mathrm{NA}$ \\
\hline
\end{tabular}

${ }^{*} \mathrm{PL}=$ Permissible Limit.

\section{Conclusion}

The EC method provides inspiring results from the treatment of pulp and paper industry wastewater. The investigation shows that the EC method is a versatile process and has the potent removal efficiency towards the BOD (Biochemical Oxygen Demand), COD (Chemical Oxygen Demand), Color, TOC (Total Organic Carbon) and TDS (Total dissolved solid) from pulp and paper industry effluent. The overall reduction in COD, Color, TOC and TDS was $82.00 \%, 99.4 \%$, 
$79 \%$ and $43 \%$ respectively; biodegradability ratio enhanced up to 0.52 at $\mathrm{pH}=$ 7.00 , current density $=25.20$, time $=40 \mathrm{~min}$ and a dose of electrolyte $1 \mathrm{~g} / \mathrm{L}$ with $100 \mathrm{rpm}$ stirring speed. The analysis was repeated in triplicate and result showed the good repeatability in the error range of $2 \%-5 \%$. All the physiochemical parameters of EC treated water were found below the permissible limit prescribed by WHO (World Health Organization) and CPCB (Central pollution Control Board); thus, can be used as an alternative to reduce the fresh water input in agriculture fields. The $\mathrm{pH}$ of the treated water after EC treatment found to be within permissible limit of environmental standard, it is obtained near neutral $\mathrm{pH}$. It is meaningful feature of EC method and not being needed neutralization process in comparison to conventional treatment.

\section{Acknowledgements}

The research grant for this study provided by the University Grant Commission, New Delhi, Government of India, is gratefully acknowledged.

\section{Conflicts of Interest}

The authors declare no conflicts of interest regarding the publication of this paper.

\section{References}

[1] Choudhary, A.K., Kumar, S. and Sharma, C. (2011) Constructed Wetlands: An Approach for Wastewater Treatment. Elixir Pollution, 37, 3666-3672.

[2] Anushree, A., Kumar, S. and Sharma, C. (2016) Ce1-xCoxOy Nanocatalysts: Synthesis, Characterization and Environmental Application. Catalysis Science \& Technology, 6, 2101-2111. https://doi.org/10.1039/C5CY01083G

[3] Ali, M. and Sreekrishnan, T. (2001) Aquatic Toxicity from Pulp and Paper Mill Effluents: A Review. Advances in Environmental Research, 5, 175-196. https://doi.org/10.1016/S1093-0191(00)00055-1

[4] Thompson, G., Swain, J., Kay, M. and Forster, C. (2001) The Treatment of Pulp and Paper Mill Effluent: A Review. Bioresource Technology, 77, 275-286. https://doi.org/10.1016/S0960-8524(00)00060-2

[5] Kumar, D., Gaurav, V.K. and Sharma, C. (2018) Ecofriendly Remediation of Pulp and Paper Industry Wastewater by Electrocoagulation and Its Application in Agriculture. American Journal of Plant Sciences, 9, 2462-2479. https://doi.org/10.4236/ajps.2018.912178

[6] Mahesh, S., Garg, K.K., Srivastava, V.C., Mishra, I.M., Prasad, B. and Mall, I.D. (2016) Continuous Electrocoagulation Treatment of Pulp and Paper Mill Wastewater: Operating Cost and Sludge Study. RSC Advances, 6, 16223-16233. https://doi.org/10.1039/C5RA27486A

[7] Chen, G., Chen, X. and Yue, P.L. (2000) Electrocoagulation and Electroflotation of Restaurant Wastewater. Journal of Environmental Engineering, 126, 858-863. https://doi.org/10.1061/(ASCE)0733-9372(2000)126:9(858)

[8] Inan, H., Dimoglo, A., Şimşek, H. and Karpuzcu, M. (2004) Olive Oil Mill Wastewater Treatment by Means of Electro-Coagulation. Separation and Purification Technology, 36, 23-31. https://doi.org/10.1016/S1383-5866(03)00148-5 
[9] Rodgers, J.D., Jedral, W. and Bunce, N.J. (1999) Electrochemical Oxidation of Chlorinated Phenols. Environmental Science \& Technology, 33, 1453-1457. https://doi.org/10.1021/es9808189

[10] Nasr, B. and Abdellatif, G. (2005) Electrochemical Oxidation of 2,4,6-Trinitrophenol on Boron-Doped Diamond Anodes. Journal of The Electrochemical Society, 152, D113. https://doi.org/10.1149/1.1904942

[11] Patel, U.D. and Suresh, S. (2008) Electrochemical Treatment of Pentachlorophenol in Water and Pulp Bleaching Effluent. Separation and Purification Technology, 61, 115-122. https://doi.org/10.1016/j.seppur.2007.10.004

[12] Mazighi, A., et al. (2015) Economic Study of Groundwater Defluoridation of the North African Sahara. Desalination and Water Treatment, 54, 2681-2691. https://doi.org/10.1080/19443994.2014.906327

[13] Martínez-Huitle, C.A. and Brillas, E. (2009) Decontamination of Wastewaters Containing Synthetic Organic Dyes by Electrochemical Methods: A General Review. Applied Catalysis B: Environmental, 87, 105-145. https://doi.org/10.1016/j.apcatb.2008.09.017

[14] Kuokkanen, V., Kuokkanen, T., Rämö, J. and Lassi, U. (2013) Recent Applications of Electrocoagulation in Treatment of Water and Wastewater-A Review. Chemistry \& Materials Science, 3, 89-121. https://doi.org/10.4236/gsc.2013.32013

[15] Särkkä, H., Bhatnagar, A. and Sillanpää, M. (2015) Recent Developments of Electro-Oxidation in Water Treatment-A Review. Journal of Electroanalytical Chemistry, 754, 46-56. https://doi.org/10.1016/j.jelechem.2015.06.016

[16] Chen, G. (2004) Electrochemical Technologies in Wastewater Treatment. Separation and Purification Technology, 38, 11-41. https://doi.org/10.1016/j.seppur.2003.10.006

[17] Zodi, S., Potier, O., Lapicque, F. and Leclerc, J.-P. (2009) Treatment of the Textile Wastewaters by Electrocoagulation: Effect of Operating Parameters on the Sludge Settling Characteristics. Separation and Purification Technology, 69, 29-36. https://doi.org/10.1016/j.seppur.2009.06.028

[18] Rajni, S., Satish, K. and Chhaya, S. (2011) Tertiary Treatment Option for Pulp and Paper Mill Wastewater to Achieve Effluent Recycling Tertiary Treatment Option for Pulp and Paper Mill Wastewater to Achieve Effluent Recycling. IPPTA, 23, 155-159.

[19] Sridhar, R., Sivakumar, V., Prince Immanuel, V. and Prakash Maran, J. (2011) Treatment of Pulp and Paper Industry Bleaching Effluent by Electrocoagulant Process. Journal of Hazardous Materials, 186, 1495-1502. https://doi.org/10.1016/j.jhazmat.2010.12.028

[20] Government of India (2018) Ministry of New and Renewable Energy.

[21] Srivastava, S.P. and Srivastava, S.P. (2013) Solar Energy and Its Future Role in Indian Economy. International Journal of Environmental Science: Development and Monitoring, 4, 81-88.

[22] Marmanis, D., Dermentzis, K., Christoforidis, A., Ouzounis, K. and Moumtzakis, A. (2014) Electrochemical Treatment of Actual Dye House Effluents Using Electrocoagulation Process Directly Powered by Photovoltaic Energy. Desalination and Water Treatment, 56, 2988-2993.

[23] Valero, D., Ortiz, J.M., Exposito, E., Montiel, V. and Aldaz, A. (2010) Electrochemical Wastewater Treatment Directly Powered by Photovoltaic Panels: Electrooxidation of a Dye-Containing Wastewater. Environmental Science \& Technology, 44, 5182-5187. 
[24] Al Suleimani, Z. and Nair, V.R. (2000) Desalination by Solar-Powered Reverse Osmosis in a Remote Area of the Sultanate of Oman. Applied Energy, 65, 367-380. https://doi.org/10.1016/S0306-2619(99)00100-2

[25] Mahesh, S., Prasad, B., Mall, A.I.D. and Mishra, I.M. (2006) Electrochemical Degradation of Pulp and Paper Mill Wastewater. Part 2. Characterization and Analysis of Sludge. Industrial \& Engineering Chemistry Research, 45, 5766-5774. https://doi.org/10.1021/ie0603969

[26] Pelegrini, R., Reyes, J., Durán, N., Zamora, P.P. and de Andrade, A.R. (2000) Photoelectrochemical Degradation of Lignin. Journal of Applied Electrochemistry, 30, 953-958. https://doi.org/10.1023/A:1004007730721

[27] Kalyani, K.S.P., Balasubramanian, N. and Srinivasakannan, C. (2009) Decolorization and COD Reduction of Paper Industrial Effluent Using Electro-Coagulation. Chemical Engineering Journal, 151, 97-104.

https://doi.org/10.1016/j.cej.2009.01.050

[28] Zodi, S., Merzouk, B., Potier, O., Lapicque, F. and Leclerc, J.-P. (2013) Direct Red 81 Dye Removal by a Continuous Flow Electrocoagulation/Flotation Reactor. Separation and Purification Technology, 108, 215-222. https://doi.org/10.1016/j.seppur.2013.01.052

[29] Daneshvar, N., Ashassi Sorkhabi, H. and Kasiri, M.B. (2004) Decolorization of Dye Solution Containing Acid Red 14 by Electrocoagulation with a Comparative Investigation of Different Electrode Connections. Journal of Hazardous Materials, 112, 55-62. https://doi.org/10.1016/j.jhazmat.2004.03.021

[30] El-Naas, M.H., Al-Zuhair, S., Al-Lobaney, A. and Makhlouf, S. (2009) Assessment of Electrocoagulation for the Treatment of Petroleum Refinery Wastewater. Journal of Environmental Management, 91, 180-185. https://doi.org/10.1016/j.jenvman.2009.08.003

[31] Vik, E.A., Carlson, D.A., Eikum, A.S. and Gjessing, E.T. (1984) Electrocoagulation of Potable Water. Water Research, 18, 1355-1360. https://doi.org/10.1016/0043-1354(84)90003-4

[32] Brillas, E., et al. (1998) Aniline Mineralization by AOP's: Anodic Oxidation, Photocatalysis, Electro-Fenton and Photoelectro-Fenton Processes. Applied Catalysis B: Environmental, 16, 31-42. https://doi.org/10.1016/S0926-3373(97)00059-3

[33] Zaied, M. and Bellakhal, N. (2009) Electrocoagulation Treatment of Black Liquor from Paper Industry. Journal of Hazardous Materials, 163, 995-1000. https://doi.org/10.1016/j.jhazmat.2008.07.115

[34] Bani-Melhem, K. and Smith, E. (2012) Grey Water Treatment by a Continuous Process of an Electrocoagulation Unit and a Submerged Membrane Bioreactor System. Chemical Engineering Journal, 198-199, 201-210. https://doi.org/10.1016/j.cej.2012.05.065

[35] Mollah, M.Y.A., Morkovsky, P., Gomes, J.A.G., Kesmez, M., Parga, J. and Cocke, D.L. (2004) Fundamentals, Present and Future Perspectives of Electrocoagulation. Journal of Hazardous Materials, 114, 199-210. https://doi.org/10.1016/j.jhazmat.2004.08.009

[36] Rajeshwar, K., Ibanez, J.G. and Swain, G.M. (1994) Electrochemistry and the Environment. Journal of Applied Electrochemistry, 24, 1077-1091. https://doi.org/10.1007/BF00241305

[37] Khansorthong, S. and Hunsom, M. (2009) Remediation of Wastewater from Pulp and Paper Mill Industry by the Electrochemical Technique. Chemical Engineering Journal, 151, 228-234. https://doi.org/10.1016/j.cej.2009.02.038 
[38] Tezcan, U., Topal, S. and Ates, F. (2016) Electrocoagulation of Tissue Paper Wastewater and an Evaluation of Sludge for Pyrolysis. Desalination and Water Treatment, 57, 28724-28733. https://doi.org/10.1080/19443994.2016.1196153

[39] Bockris, J.O., Conway, B.E., Yeager, E. and White, R.E. (1981) Comprehensive Treatise of Electrochemistry: Electrochemical Processing. Springer, Berlin.

[40] Nassar, M.M., Fadaly, O.A. and Sedahmed, G.H. (1983) A New Electrochemical Technique for Bleaching Cellulose Pulp. Journal of Applied Electrochemistry, 13, 663-667. https://doi.org/10.1007/BF00617824

[41] Alverez-Gallegos, A. and Pletcher, D. (1999) The Removal of Low Level Organics via Hydrogen Peroxide Formed in a Reticulated Vitreous Carbon Cathode Cell. Part 2: The Removal of Phenols and Related Compounds from Aqueous Effluents. Electrochimica Acta, 44, 2483-2492. https://doi.org/10.1016/S0013-4686(98)00371-5

[42] Lucas, M.S. and Peres, J.A. (2009) Removal of COD from Olive Mill Wastewater by Fenton's Reagent: Kinetic Study. Journal of Hazardous Materials, 168, 1253-1259. https://doi.org/10.1016/j.jhazmat.2009.03.002

[43] Lazarova, V., Hills, S. and Birks, R. (2003) Using Recycled Water for Non-Potable, Urban Uses: A Review with Particular Reference to Toilet Flushing. Water Science \& Technology Water Supply, 3, 69-77. https://doi.org/10.2166/ws.2003.0047

[44] Rezende, A.A.P., de Matos, A.T., Silva, C.M. and Neves, J.C.L. (2010) Irrigation of Eucalyptus Plantation Using Treated Bleached Kraft Pulp Mill Effluent. Water Science \& Technology, 62, 2150-2156. https://doi.org/10.2166/wst.2010.945

[45] Kiziloglu, F.M., Turan, M., Sahin, U., Kuslu, Y. and Dursun, A. (2008) Effects of Untreated and Treated Wastewater Irrigation on Some Chemical Properties of Cauliflower (Brassica olerecea L. var. botrytis) and Red Cabbage (Brassica olerecea L. var. rubra) Grown on Calcareous Soil in Turkey. Agricultural Water Management, 95, 716-724. https://doi.org/10.1016/j.agwat.2008.01.008

[46] Gaurav, V.K., Kumar, D. and Sharma, C. (2018) Assessment of Metal Accumulation in the Vegetables and Associated Health Risk in the Upper-Most Ganga-Yamuna Doab Region, India. American Journal of Plant Sciences, 9, 2347-2358. https://doi.org/10.4236/ajps.2018.912170

[47] Vigneswaran, S. (2004) Recycle and Reuse of Domestic Wastewater Waste Recycle, Reuse, and Reclamation. Encyclopedia of Life Support Systems (EOLSS), Developed under the Auspices of the UNESCO, Eolss Publishers, Oxford.

http://www.eolss.net..eolss.net 